\title{
THE DIALOGUES BETWEEN KRESNA AND ARJUNA CONCERNING THE SWADARMA OF A KSATRIYA IN THE BHAGAVAD GITA OF THE ANCIENT JAVANESE BHISMA PARWA
}

\section{(Dialog Kresna dan Arjuna tentang Swadharma Ksatriya Episod Bhagavad Gita dalam Bhisma Parwa Jawa Kuno)}

\author{
I Made Suastika \\ made.suastika57@yahoo.com
}

Faculty of Arts,

Udayana Universiti, Denpasar,

Bali, Indonesia.

\begin{abstract}
The Bhagavad Gita is usually called the fifth veda (pancama veda), together with the four Sanskrit Vedas, namely the Rig Veda, Atharwa Veda, Sama Veda and Yajur Veda. The Balinese are familiar with the five vedas, and know the Bhagavad Gita as the sixth book of the ancient Javanese version of the Mahabharata epic. The Bhagavad Gita that features as a part of the ancient Javanese version of the Bhisma Parwa is ascribed to King Teguh Dharmawangsa Anantavikrama Uttunggadewa of the Kediri Kingdom in the 10 th century $\mathrm{CE}$. He is credited to have been responsible for ordering the translation of the Mahabharata (known in Bali as Asta Dasar Parwa-the 18 parwas). This translation effort from Sanskrit into the ancient Javanese language was dubbed mangjawaken Byasamata (translating into Javanese the works of the sage Byasa). The ancient Javanese version of the Bhagavad Gita contains the dialogues between Kresna and Arjuna about the swadarma (holy obligations and responsibilities) of a ksatriya (warrior) according to his wangsa (social class). A ksatriya was deemed responsible for defending
\end{abstract}


his country, fighting against the enemy, as well as for upholding truth, satya wacana (truthfulness), lascarya (sincerity) and sradha bhakti (devotional service).

Keywords: Bhagavad Gita, Asta Dasa Parwa, satya wacana, lascarya, bhakti

\begin{abstract}
Abstrak
Bhagavad Gita sering disebut veda yang kelima (pancama veda) disamping empat veda yang ada, iaitu Rig Veda, Atharwa Veda, Sama Veda dan Yajur Veda berbahasa Sanskrit. Di Bali kelima-lima veda itu, termasuk Bhagavad Gita yang terdapat pada teks Bhisma Parwa, buku ke-6 daripada Mahabharata versi Jawa kuno. Empat veda dan Bhagavad Gita telah dibaca oleh masyarakat Bali dalam rangka mendapatkan ajaran tuhan untuk memperkuat nilai etika dan moral. Episod Bhagavad Gita berbahasa Jawa kuno terdapat dalam Bhisma Parwa digubah oleh Raja Teguh Darmawangsa Anantavikrama Uttunggadewa pada abad ke-10 Kerajaan Kediri. Raja Dharmawangsa Teguh menjadi manggala dalam penciptaan Mahabharata (di Bali disebut Asta Dasa Parwa atau 18 Parwa) memerintahkan rakawi untuk menyadurnya. Program alih bahasa yang disebut Mangjawaken Byasamata (mengalihbahasakan ajaran Begawan Byasa) yang sumbernya berbahasa Sanskrit kepada bahasa Jawa kuno. Bhagavad Gita Jawa kuno berisi dialog antara Krisna dan Arjuna tentang fungsi seorang kesateria dalam melaksanakan swadharma, iaitu tugas atau kewajiban suci seorang kesateria berdasarkan kelahirannya (wangsa). Tugas seorang kesateria adalah untuk membela negara dan mempertahankan negara, berperang melawan musuh, membela kebenaran, membela ucapan (satya wacana) dengan tulus ikhlas (lascarya) dan pengabdian (sradha bhakti).
\end{abstract}

Kata kunci: Bhagavad Gita, Asta Dasa Parwa, satya wacana, lascarya, bhakti

\title{
INTRODUCTION
}

The Bhagavad Gita is known as the fifth veda (pancama veda), after the four Vedas, namely the Rig Veda, Atharwa Veda, Sama Veda and Yayur Veda. The Balinese people are familiar with these five vedas, which guide their Hindu sradha (faith). The texts are accessible to the Indonesian people in general and the Balinese people in particular and are Hindu religious texts that serve as references for strengthening their understanding of ethical, moral and universal values.

The Sanskrit version of the four vedas (Rig Veda, Atharwa Veda, Sama Veda and Yayur Veda) using the ancient Indian Devanagari script was not 
known in the Indonesian Archipelago. Similarly, only very recently were the Balinese exposed to the Sanskrit vedas written in the Devanagari script, in around 1959 (interview with Sudiana, 2014). The Vedas were translated into the Indonesian language by I Made Tilib (2003) and titled Sabda Suci Pedoman Praktis Kehidupan (Holy Words of Wisdom for Daily Practice). However, this version was not a complete one; it only contained a number of verses, which, according to the translator, were to be used to strengthen the Balinese people's shrada (faith) in their daily life. In a similar vein, the Yayur Veda, which contains knowledge relevant to the medical sciences, was developed by the Yayur Veda study programme at the Hindu University of Indonesia, Denpasar, and was well received not only by students of the study programme but also by the Balinese people in general.

\section{THE ANCIENT JAVANESE BHAGAVAD GITA IN THE BHISMA PARWA}

The exact date when the Sanskrit version of the Bhagavad Gita - as written in the Indian Devanagari script in the form of poems - was introduced and flourished in the Indonesian Archipelago is unknown. It has been suggested that the Bhagavad Gita was introduced in Bali in 1959 (interview with Sudiana, 2014). The ancient Javanese language version, a prose version, has existed in the Archipelago since the 10th century CE, when King Dharmawangsa Teguh (Teguh Dharmawangsa Anantavikrama Uttungga Deva) ruled the Kadiri (Kediri) Kingdom. It was on his orders that the rakawi (court poet) had translated the Mahabharata text, which in Bali is known as Asta Dasa Parwa (The 18 Parwas). This venture was called mangjawaken Byasamata, and was a large-scale translation effort to render the writings of Byasa into the ancient Javanese language. This translation of Byasa's work can be considered as an adaptation of the Mahabharata text in the ancient Javanese language (Zoetmulder, 1994).

The Bhagavad Gita, which is a part of the Mahabharata, is found in the Bhisma Parwa text (Asta Dasa Parwa), the sixth parwa or book. It deals with the first day that Bisma leads his people in the Bharatayudha war. It is this Bhisma Parwa text, which is written in the ancient Javanese language, that contains the dialogues between Kresna and Arjuna of the holy obligations and responsibilities (dharma/swadharma) of a ksatriya (warrior) as according to his wangsa (social class). He is responsible for defending the country, fighting against the enemy, defending the truth, being truthful (satya wacana), sincere (lascarya) and full of devotion (bhakti). 
The following is a summary of the dialogues between Kresna and Arjuna found in the in the Bhagavad Gita of the Bhisma Parwa:

In the beginning, Arjuna is confused and apprehensive when he reaches the battle field. In the midst of the combat he asks his charioteer, Kresna, to stop. He sees his relatives, former teacher and those whom he was familiar with siding with the enemy; he is so affected that he almost relinquishes his leadership of the Pandawa in the war. He thinks that civil war is contrary to dharma (cosmic order). He prefers to lay down his arms and allow himself to be killed by the enemy without any resistance. Kresna explains that this is the wrong attitude for a ksatriya (warrior). Then Kresna conveys to him the "pure knowledge" which remits all kinds of depression. The body is impermanent; it is able to defeat, or able to be defeated. Defeating and being defeated are the same. One should perform the divine duty (darma). For a ksatriya, this means fighting in a war. Were he to die, he would go to heaven; were he to win, he would become powerful in this world. However, if he does not do what he is supposed to do, he will be punished and looked upon contemptuously by the whole world. One should only direct one's mind to one's swadharma, namely, one's divine duty, whatever one's social position; one should free oneself from other cares (lascarya). Man should not be controlled by his emotions, be they sadness or happiness; his heart should be free from depression. Kresna also reveals that he is actually the Deity Wisnu, who is constantly reincarnating in order to save the world. Recognizing him as Wisnu, and following his actions in this world, that is, sepi ing pamrih (without expecting a reward), would result in the final liberation from rebirth. Upon Arjuna's request, Wisnu-Kresna reveals himself entirely to Arjuna. He says he is the source of all things in the world. He gives Arjuna the ability to see what he looked like physically and everything is revealed within him. He also shows himself as kala (time) which can destroy everything (the Deity Kala and Wisnu Murti). Arjuna sees the Korawas swallowed by Kresna and thus destroyed. Sensing Arjuna's fear, he returns to his more friendly form. The last warning given by Kresna finally causes Arjuna to devote himself to Kresna. Soon after, Arjuna does not feel sad and restrained any longer. This is the end of the revelation.

Arjuna is then ready to take up his weapon and jumps right into the battle, fulfilling his duty as a warrior by fighting against the enemy.

(Zoetmulder, 1994: 90-91).

The following are some examples of dialogue between Kresna and Arjuna in Bhagavad Gita written in the ancient Javanese language are as follows (Gonda, 1936). 
In a war, the holy responsibility of a warrior is performing what is referred to as darma ksatriya:

... kunang pějah ni těngah ning ranāngga ya ika, mahāwisesa ning kadi kita mahaksatriya ngaranya.

( $\ldots$ as for dying in battle, it is the greatest thing for a warrior like you, such a one will be called a great warrior.) (p. 36)

Arjuna's feelings of hesitation and apprehension which he expresses to Kresna in the battle field are described as follows:

... Arjuna tan wěnang aprang, melas arěp manastapa citanira (yang diajak berperang)... Sang rowanga ing apranga katon ta sira kabeh, kapwa kulawarga, bapa kaki paman, pangajyan guru wwang sanak kaka ranak putu parnahnya kabeh... (pp. 40-41)

(... Arjuna did not want to fight, begged to be pitied and was full of sorry; those that he saw on the battlefield were his family, father, older siblings, uncles, teachers, younger brothers, older brothers, grandsons; they were all his relatives ...) (pp. 40-41)

The advice given by Kresna to Arjuna is that, as a warrior, Arjuna should strongly take hold of what is referred to as buddhi kaksatriyan (warriorly instinct).

The text quoted from Bhagavad Gita is as follows:

... tan dadi $n$ kadi sang arya makamběk kasudracitta si gong prihati, wanguněn pwa budhi kaksatriyan de rakryan, ya ta nyan tan ilanga svarga lawan yasanta, sang arya karaketan prihati,jňana nirmala pwa pwajarakěna pati urip kapweka tan kinakungakěn de sang wihikan, nihan ling sang hyang agama. Janma muda-tua tan hana pahinya. (p. 42)

( $\ldots$ one should not be like Sang Arya (Arjuna) and feel depressed and sad; pull yourself together and return to your warlike self, Sire. In this way, you will not lose your chance for heaven and the reward for your deeds. Sang Arya (Arjuna), you are tied down by your sadness, you should clear your mind. For great men, there is no difference between life and death. To the deity, it is the same. There is no difference between old and young.) (p. 42) 
Sifat orang wihikan tidak sedih kedatangan kematian (mati kalawan ahurip), panas tis, suka duka sama surasa wirasa. (p. 43).

(The nature of the great man is that he will never feel sad whether he is alive or dead, hot or cold, happy or sad; the tasty and the bland are the same to him. (p. 43).)

Kresna repeats again that the swadharma (the divine duty) of a warrior is that he must not forget his dharma yuddhakarma (duty to war for righteousness). If he did not perform his dharma yuddhakarma, he would be, as quoted from the text of Bhagavad Gita:

... bisama $n$ kirti kathinghal, kapanggih papa magring, niyata ginuyu-guyu de sang mahavira, upětěn de sang singhapurusa, ikang ulah tininda dening surajaya, yeka duhka mahabhara ring rat, pagěha jñana kumwa ... mara buddhinta ring Samkhya yoga, ikang budi wyawasa yatmaka, apan anghing rakwa ika lewih yan ěngke ring loka, yawat buddhi mangekanteng svadarmakarya, gěgonta pwa amběk mangkana. Luput miyatanta ring karma bandhana ... yoga teka gègonta. (p. 44)

[Dharma yuddhakarma ... if a warrior does not hold fast to his promise of kirtti (fame), he will be in misery and pain, and will be laughed at by the great men. He will be mocked by the soldier and the brave and will encounter excessive sorrow in this world; therefore, hold fast, concentrate on the samkhya yoga (religious philosophy) — be as strong as possible; that is the best for you on earth; concentrate on your swadarmakarya (dutiful actions); if you hold fast to such thoughts, you will be free from the shackles of actions ... this is the yoga (philosophy) to which you should hold fast.] (p. 44)

There is more advice from Kresna in the Bhagavad Gita, for example in the following excerpt:

... pinakangkulun ikang sinangguh laksana ning mahapurusa (yang disebut) pradyan hana wwang tan alara n katěkan duhka mahabhara ...ing raga bhaya krodha, apageh ta yen budhi ... mahapurusa samangkana. (p. 45)

[Someone is stated to be wise and smart (clever) if he/she is not sad when sadness comes to him/her. ... If he/she is in a danger 
and seriously angry, he strongly controls his/her mind for which he/she is referred to as mahapurusa (and so forth).] (p. 45).

In the dialogue between Kresna and Arjuna, Kresna mentions his many names, depending on his functions; he can be appear as Kala, who can destroy the world at an instance; he can take the form of Wisnu, as whom he is the source of everything and the ultimate destination of life on earth (p. 61-62).

Sanghyang atma is the soul that occupies the body; it is holy, unblemished (karakètan mala) has no pragmatic function (ng guna) and is invisible. Atma is the soul, while sarira is the body. Those who come to know atman (the soul), will achieve kaparamarthan (insight). While the soul is pure, the body is influenced by three components of the mind known as triguna: satwam (goodness), rajah (passion), and tamah (ignorance). Those who cannot control these three components will experience janma sangsara (human suffering). Therefore, the triguna should be understood and controlled in the mind, and be balanced. Arjuna's flaw was that he was unable to keep his triguna under control, and is considered to be too inclined to his triguna (p. 63).

In the next dialogue between Kresna and Arjuna, Kresna guarantees that those who are devoted to him will go to heaven. Quoted from the text of Bhagavad Gita:

... yan hana wwang bhakti ri nghulun, tatan wyabicara kasewakanya, yeka wěnang malahakèn tribhuwana, byakta mantuk ring swargaloka pwa ya ta. ...denya, patinggal irikang swadharma, kewala nghulun juga karana nika, apan wěnang hulun mantasakěna sangke gawenya hala, haywa tasan prapancatura t atuhunan prihati kadiwasa ng manastapa.

Sajña haji, maharaja Kresna hilang ike punggung ning pinakang hulun, mahěli tutur kalawan kamedhan, makanimitta sih rahadyan sanghulun apagěh tâmběk ni nghulun mari sandeha rasany ajnya rahadyan sanghulun damělakěna patik haji mangke. (p. 65)

[Those who are devoted to me (Kresna) and do not shirk their swadharma (divine duty) as dictated by the class they are born into can escape the three worlds. They will certainly go to heaven. ... I (Kresna) am the only one who can release people from their divine duties because I can avert that which is not good. Do not let confusion cause you to suffer; do not let your mind cause you to be miserable.

Your Excellency Kresna, I am not confused (ignorant) any longer; 
I recognize that I should listen to your wise words. Because you take pity on me, my mind is becoming stronger; I am not doubtful any longer. I (Arjuna) will do what you ask me to do.] (p. 65)

Arjuna stands up after listening to Kresna's advice, as described in the following dialogue from the text of Bhagavad Gita:

... Nahan pangucap maharaja Kresna lawan sang Arjuna, atěhěr sira maluyakěn suarupa nira jati Kresna, agirang te sang Dhananjaya de nikang yoga sastrânugrahê sira ... enak de nira ruměgép capa nira.

(... Such was the dialogue between the great Kresna and Arjuna. Arjuna became weak when Kresna revealed his true form. In the end, Arjuna held his bow with gladness.) (p.65)

\section{THE SANSKRIT VERSION OF THE BHAGAVAD GITA IN BALI}

At present, there are two versions of the Bhagavad Gita in Indonesia in general, and in Bali in particular: one that is written in the ancient Javanese language as part of the Bhisma Parwa, as aforementioned, and another written in Sanskrit using the Devanagari script. It was compiled and published by Pendit (1966) and reprinted in 1995. There are also a number of other translations of the Sanskrit Bhagavad Gita such as editions undertaken by Ramananda Prasad, Svami Rangganathananda, Sri Sramad Ac Bhakti Vedanta, and S. Radhakrisnan.

Bhagavad Gita, "The Divine Song", is a part of Mahabharata (Bhisma Parwa), and since it contains the words of Kresna to Arjuna, it is taken to be a holy text. Kresna is the reincarnation of god and the Bhagavad Gita contains knowledge (vedanta) and ethics.

The part of Bhagavad Gita that is concerned with knowledge (vedanta) is verse XV.15:

Sarvasya cha ham hridi samnivishto

Mattah smritir jnanam apohanam cha

Vedais cha sarvair aham eva vedyo

Vedantakrid vedavid eva cha ham

(In truth, I am in the heart of every creature

Memory, knowledge, forgetfulness are from me 
I am the one that should be known by the holy vedas

I created the vedanta and it is me who is the knower of the vedas.)

Generally, the essence of Bhagavad Gita in Sanskrit is made up of 18 dialogues, 700 sloka (verses) (Pendit, 1995) as follows.

\begin{tabular}{|c|c|c|}
\hline Dialogue1 & $\begin{array}{l}\text { about Arjuna - Visendayoga } \\
\text { Approaching the soldiers in the battle field }\end{array}$ & (47 slokas) \\
\hline Dialogue 2 & $\begin{array}{l}\text { about Samkhyayoga } \\
\text { Summary of the contents of Bhagavad Gita / } \\
\text { Arjuna's hesitation }\end{array}$ & (72 slokas) \\
\hline Dialogue 3 & $\begin{array}{l}\text { about Karmayoga } \\
\text { Natural law and how to works } \\
\text { (work discipline) }\end{array}$ & (43 slokas) \\
\hline Dialogue 4 & $\begin{array}{l}\text { about Jnanayoga } \\
\text { Spiritual knowledge/devotion (Brahman) }\end{array}$ & (42 slokas) \\
\hline Dialogue 5 & $\begin{array}{l}\text { about Karmasamnyasayoga } \\
\text { Karma yoga: Deeds in Kresna's Consciousness } \\
\text { (ethics and freedom) }\end{array}$ & ( 29 slokas) \\
\hline Dialogue 6 & $\begin{array}{l}\text { about Dhyanayoga } \\
\text { Dhyanayoga (the true yoga) }\end{array}$ & (47 slokas ) \\
\hline Dialogue 7 & $\begin{array}{l}\text { about Jnana vijnanayoga } \\
\text { Knowledge of the absolute (the deity and the world) }\end{array}$ & (30 slokas) \\
\hline Dialogue 8 & $\begin{array}{l}\text { about Akshara Brahmayoga } \\
\text { Way of attaining the supreme (cosmic evaluation) }\end{array}$ & (28 slokas) \\
\hline Dialogue 9 & $\begin{array}{l}\text { about Raja Vidya Rajaguhyayoga } \\
\text { Knowledge of the greatest secret }\end{array}$ & (34 slokas) \\
\hline Dialogue 10 & $\begin{array}{l}\text { about Vibhutiyoga } \\
\text { The absolute devine superiority (the source of all } \\
\text { things) }\end{array}$ & (42 slokas) \\
\hline Dialogue 11 & $\begin{array}{l}\text { about Visvarupa Darsanayoga } \\
\text { The universal form, the manifestation of the deity } \\
\text { (Brahman) }\end{array}$ & (55 slokas) \\
\hline Dialogue 12 & $\begin{array}{l}\text { about Bhaktiyoga } \\
\text { Devotion to Brahman }\end{array}$ & (20 slokas) \\
\hline Dialogue 13 & $\begin{array}{l}\text { about Kshetra Kshetrajna Vibhagayoga } \\
\text { Nature, the enjoyer and consciousness (the body } \\
\text { and the soul) }\end{array}$ & (27 slokas) \\
\hline
\end{tabular}


MALAY LITERATURE VOLUME 29 NUMBER 2 DECEMBER 2016

\begin{tabular}{|c|c|c|}
\hline Dialogue 14 & $\begin{array}{l}\text { about Guna Trayavibhagayoga } \\
\text { The three modes of material nature } \\
\text { (Brahman-prakerti-guna) }\end{array}$ & (27 slokas ) \\
\hline Dialogue 15 & $\begin{array}{l}\text { about Purushottamayoga } \\
\text { The yoga of the supreme person }\end{array}$ & (20 slokas) \\
\hline Dialogue 16 & $\begin{array}{l}\text { about Daivasurasampadvibhagayoga } \\
\text { The nature of the devine and undevine }\end{array}$ & (24 slokas) \\
\hline Dialogue 17 & $\begin{array}{l}\text { about Sarddhatrayavibhagayoga } \\
\text { The three kinds of faith (Triguna) }\end{array}$ & (28 slokas) \\
\hline Dialogue 18 & $\begin{array}{l}\text { about Samnyasayoga } \\
\text { The perfection of liberation from work (lascarya) } \\
\text { to reach to Brahman }\end{array}$ & (78 slokas) \\
\hline
\end{tabular}

\section{THE CURRENT UNDERSTANDING OF THE BHAGAVAD GITA AMONG THE BALINESE}

The Bhagavad Gita contains three important parts. Part one contains dialogues 1 to 6 which describe work discipline without expectation of reward (lascarya) and the nature of the soul in the body; part two contains dialogues 7 to 12 which deal with the discipline of knowledge (vedanta) and devotion to Brahman; part three contains dialogues 13 to 18 which conclude what is stated in the previous parts. They also deal with the discipline of knowledge of the entire body and soul and work activities that are to be made for the eternal Brahman.

The entire content of Bhagavad Gita in Sanskrit, which is part of the Bhisma Parwa (the sixth parwa of Mahabharata), is also known as the fifth holy book/veda after Rig Veda, Sama Veda, Yayur Veda and Atharwa Veda. Chapters 23 to 40 of the Bhisma Parwa contain the dialogues between Kresna and Arjuna, estimated to have been composed around 450 to 400 years before the common era, and these dates imply that this is also the time when the original Bhagavad Gita was composed (Pendit, 1995: xviii).

The Bhagavad Gita, which is full of philosophy, is a darmasastra-a book that contains guidance to good deeds, and smrti, namely, knowledge that should always be borne in mind and be used as guidance to do what is right (Pendit, 1995: xx).

The essence of the dialogues between Kresna and Arjuna about swadarma (holy obligations and responsibilities), karma yoga (selfless actions and service) and samnyasa (renunciation), which is found in the Bhagavad Gita, is as follows: 
(1) Arjuna is confused, hesitant, and frustrated when he is at Kuruksetra; therefore, he asks Kresna for his advice.

II.7. I would like to ask you for your accurate explanation on what my duties and responsibilities are; I am your disciple, I come to you to ask for your protection and advice.

(2) The Avatar of Wisnu (Kresna) asks Arjuna not to be confused any longer, and says to Arjuna

IV.10. Whatever is done by man to reach me is welcome, They all come to me, oh son of Parta.

(3) When Arjuna is no longer confused and does not hesitate, Kresna gives his last message:

XVIII.89 If satisfying your egotism

You think that "I do not wish to fight"

This is a vain determination

Your prakriti (nature) will force you

XVIII.65 Concentrate your mind on me, be devoted to me. Kneel before me, worship me, you will reach me, I sincerely promise to you, as someone whom I love.

XVIII.66 When you leave your duties and responsibilities, do come to me only for protection; do not be sad, as I will free you from all sins.

(4) Karma yoga and Samnyasa

Every creature is equal; that is the dialogue between Kresna and Arjuna about karma yoga. The Bhagavad Gita teaches that we should have an insight into life. The value of someone's life should be viewed with consideration of his/her swadarma. It is one's own duties and obligations to attain the truth that differentiate one from others, not one's work or possessions. It is the extent of one's devotion to the 
deity, one's country nation and one's community that differentiate one from others. Thus, the word yoga (karma yoga) which refers to swadarma and samnyasa, means working selflessly.

V.10 He who works and surrenders the results to Brahman without any selfish motive will not be touched by sin, just as water cannot stay on a lotus leaf.

\section{THE BHAGAVAD GITA LEADS MAN TO SPIRITUAL AND PHYSICAL BALANCE}

The Bhagavad Gita contains knowledge, vedanta, and moral or ethical lessons, and is thus the pearl of goodness presented in the form of dialogues between Kresna and Arjuna. It should be read as it contains divine values. The Bhagavad Gita has ethical, moral and spiritual lessons that are universal in nature. Such values can be used to empower and strengthen man and society.

One who wishes to comprehend the Bhagavad Gita should begin with bhakti yoga (respect and kneel before Kresna) and follow his teachings and advice. Devotion to him is mentioned in the Bhagavad Gita IX.14:

The great souls always praise my greatness,

Endeavour with great determination

Kneel before me, and always worship me with devotion

Bhagavad Gita 18.65:

Always think about me, be my worshipper

Pray to me and kneel before me,

In this way, you will certainly come to me

I promise you, as my friend whom I dearly love.

What can be gathered from the text of the Bhagavad Gita through the dialogues between Kresna and Arjuna is that life in this era of globalization is full of challenges that human beings must face, especially because of moral decay resulting from negative impact of globalization, and negative factors more directly linked to the individual, such as the food one eats, a materialistic way of life, free mingling of the sexes, information incompatible with native cultures, and violence.

The values and teachings in the Bhagavad Gita are precious pearls from the eastern part of the world. It is this eastern local wisdom that one could 
use to overcome the moral degradation in human life in the current era of globalization. Humankind should try and understand the philosophy of triguna (satwam, rajas and tamas); humankind should not be excessively proud of itself; it should avoid any form of violence; it should be tolerant, simple, and constantly seeking spiritual knowledge from a trusted guru; it should be able to control itself; be able to free itself from the lusts of wanting to satisfy the five senses; it should not be excessively egoistic; it should understand what birth, death, old age and diseases are; it should be free from both pleasant and unpleasant events; it should always be devoted to the deity (Kresna); it should always feel that it is a part of the public (trsna); it should be aware, and understand the truth (the deity).

The practical aspects gleaned from the Bhagavad Gita are loving one another, satyam (truthfulness), tapasya (self-control) and saucam (self purification). And through this, to balance dharma and morality in order to achieve the balance for body and soul.

At the end of this paper, I would like to quote from the work of Ida Padanda Made Sidemen, a Hindu Priest, who lived in Sanur in the 19th and 20th century about the concept of work and learning in preparing ourselves, especially since we live in a competitive and globalized era, to face these challenges, and become useful to others (guna dusun) and "plant the internal garden" (karang awake tandurin). There are three stages, according to him, which we will need to go through in order to improve achievement and self quality: darma yatra (pilgrimage of exploration), darma karya, and lascarya; he writes about these in his work, Salampah Laku (The Pilgrimage That Must Be Made).

Similar opinions are expressed by Prof. Dr. Paerbatjaraka, the former Dean of the Faculty of Cultural Sciences of Gajah Mada University, and the first Dean of the Faculty of Cultural Knowledge at Udayana University (1958). In his speech at the inauguration of the faculty, he said,

Bagi saya membaca sastra-sastra Jawa Kuna, terutama Ramayana dan Mahabrata yang mengandung nilai filosofis sangat berguna bagi kehidupan. Untuk itu, saya kira memahami nilai itu akan lebih banyak mendapatkan kebaikan daripada keburukan, menuju kebaikan hidup daripada kesengsaraan.

(To me, reading the literary works written in the ancient Javanese, especially Ramayana and Mahabrata, which contain philosophical values, is highly useful in life. Therefore, I think that understanding 
such values will result in more good than bad, and lead towards the good in life, rather than to misery.)

\section{CONCLUSION}

The Hindu ethic exists because of the need to explain individual needs, emotions and ambitions and lead people to a harmonious life on earth; with the ultimate aim of Hinduism being to make the individual's existence about awareness of the self. What is meant by 'awareness of the self' is that to be conscious of themselves and the deity as the source and essence of human awareness and freedom (Pandit, 2005: 135).

Basically, the Hindu ethic is the same as that of other religions on earth. It gives emphasis on what is good such as (1) self control, charity, and love; (2) seclusion; (3) truth; (4) anti-violence; and (5) yajna (ritual sacrifice). This can be found in dialogue 16, verses 1 to 10 of the Bhagavad Gita.

Thus, Bhagavad Gita, the divine song, contains satyam (the truth), sivam (godliness) and sundaram (beauty). They are the important philosophical foundation of life in Bali. Sundaram appears in the form of the Bhagavad Gita itself, and satyam and sivam are in the content of this great literary work.

\section{REFERENCES}

Gonda, J., 1936. Het Oudjavaansche Bhismaparwa. Bandung, AC Nix Co.

Pandit, Basui, 2005. The Hindu Mind (Pemikiran Hindu). Indonesianized by IGA Dewi Paramitha. Surabaya: Paramita.

Pendit, Nyoman S., 1995. Bhagavad Gita. Jakarta: Hanoman Sakti.

Radhakrisna, S., 2009. Bhagavadgita. (Indonesian translation by Yudhi Murtanto). Yogyakarta: Ircisod.

Titib, I Made, 2003. Weda: Pedoman Praktis Kehidupan. Surabaya: Paramita. Zoetmulder, P.J., 1982. Kamus Jawa Kuna-Indonesia. Indonesianized 1995. Jakarta: Penerbit PT. Gramedia Pustaka Utama.

Zoetmulder, P.J., 1994. Kalangwan: Sastra Jawa Kuna Selayang Pandang. Jakarta: Penerbit Djambatan.

Received: 5 January 2016

Accepted: 27 June 2016 